\title{
Analisis Pengaruh Waktu Artificial Age Terhadap Kekerasan, Densitas Dan Struktur Kristal Paduan Alumunium (7075) Untuk Bahan Sirip Roket
}

\author{
Budiarto ${ }^{1,}{ }^{*}$, Dikky Antonius ${ }^{1}$, Brillian Ardiana Putra ${ }^{1}$ \\ 1 Teknik Mesin, Fakultas Teknik, Universitas Kristen Indonesia; Jl. Mayjen Sutoyo no.2 \\ Cawang - Jakarta 13630 Indonesia, e-mail: budidamaz@gmail.com, \\ brillianardianaputra@gmail.com \\ * Korespondensi: e-mail: budidamaz@gmail.com
}

\begin{abstract}
A heat treatment study has been carried out on Al 7075 alloys. Al 7075 Alloys have strong, lightweight, corrosion resistant, and good thermal conductivity properties. To meet the requirements of the Al-7075 alloy, a T6 heating process can be used. The T6 process begins with heated solid solution at temperatures above $570{ }^{\circ} \mathrm{C}$ held for 1 hour, then dip it quickly in water media, as well as the artificial aging process time variations of 1, 4, and 20 hours at a temperature of $210^{\circ} \mathrm{C}$. After the cooling process, the specimen is then carried out metallographic process. Characterization of hardness by Vickers scale, obtained that Al 7075 alloy without heat treatment gave a hardness rate of $84.1 \mathrm{HV}$. Al 7075 test sample which heat treatment gave the highest hardness value of $144.90 \mathrm{HV}$ obtained at a combination of aging temperature of $210^{\circ} \mathrm{C}$ aging time of 20 hours, an increase in hardness value of $42.96 \%$. The crystal structure test using Scanning Electron Microscope (SEM), showed that the Al 7075 test sample without heat treatment showed the dominant Al matrix, whereas in the Al 7075 test sample after going through the T6 process, the CuA12, AlCuMg, MgZn2 phases were used to harden the alloy. Crystal size, dislocation density, and crystal lattice strain with X-Ray Diffraction $(X R D)$, indicate an increase in crystal size as the heating time of artificial aging increases. While the dislocation density and lattice strain increase during the artificial aging period of 1 hour and 4 hours, then at 20 hours experience a decrease in dislocation density and lattice strain.

Keywords: Al-7075 alloys, artificial aging, T6, hardness, Vickers, crystal structure, crystal size, dislocation density, lattice strain.
\end{abstract}

\section{Abstrak}

Telah dilakukan studi perlakuan panas terhadap paduan Al 7075. Paduan Al 7075 mempunyai sifat kuat, ringan, tahan korosi, dan konduktifitas termal yang baik. Untuk memenuhi syarat paduan Al-7075 dapat dipakai dilakukan proses pemanasan T6. Proses T6 dimulai dengan dipanaskan solid solution pada suhu diatas $570^{\circ} \mathrm{C}$ ditahan selama 1 jam, kemudian celup cepat di media air, serta proses penuaan buatan (artificial aging) variasi waktu 1, 4, dan 20 jam pada suhu $210^{\circ} \mathrm{C}$. Setelah proses pendinginan, spesimen ini kemudian dilakukan proses metalografi. Karakterisasi kekerasan dengan skala Vickers, diperoleh bahwa paduan Al 7075 tanpa perlakuan panas memberikan angka kekerasan sebesar 84,10 HV. Sampel uji Al 7075 yang mengalami perlakuan panas memberikan nilai kekerasan tertinggi sebesar 144,90 HV diperoleh pada kombinasi temperatur aging $210^{\circ} \mathrm{C}$ waktu aging 20 jam, terjadi kenaikan nilai kekerasan sebesar 41,96\%. Pengujian struktur kristal dengan Scanning Electron Microscope (SEM), menunjukkan bahwa pada sampel uji Al 7075 tanpa perlakuan panas terlihat matriks Al yang dominan, sedangkan pada sampel uji Al 7075 setelah melalui proses T6 memunculkan fasa CuA12, AlCuMg, MgZn2 yang berfungsi mengeraskan paduan. Ukuran kristal, kerapatan dislokasi, dan regangan kisi kristal dengan X-Ray Diffraction (XRD), menunjukkan bertambahnya ukuran kristal seiring dengan lamanya waktu pemanasan penuaan buatan. 
Submitted: 7 Nopember 2019; Revised: 21 Nopember 2019; Accepted: 5 Desember 2019; Published: 25 Januari 2020

Sedangkan densitas dislokasi dan regangan kisi meningkat selama periode waktu pemanasan 1 jam dan 4 jam, lalu pada waktu 20 jam mengalami penurunan densitas dislokasi serta regangan kisi.

Kata Kunci: Paduan Al-7075, penuaan buatan, T6, kekerasan, Vickers, struktur kristal, ukuran kristal, kerapatan dislokasi, regangan kisi.

\section{Pendahuluan}

Roket adalah suatu benda diluar angkasa berputar mengelilingi planet (bumi) dengan rotasi dan orbit tertentu. Struktur adalah hal yang tidak terpisahkan dari Roket. Pada umumnya struktur Roket terdiri dari struktur utama (main structure) dan struktur penunjang (secondary structure). Struktur utama adalah struktur yang berfungsi sebagai tempat untuk meletakkan seluruh subsistem Roket dan mentransmisikan beban ke dasar Roket. Struktur penunjang adalah melekat pada struktur utama Roket yang berfungsi sebagai penunjang untuk mendukung diri mereka sendiri seperti baffel, pelat solar panel, dan dudukan subsistem. Fungsi dari struktur Roket adalah sebagai tempat untuk meletakkan subsistem, penghubung (interface) dengan wahana peluncur/Roket, dan sebagai pelindung subsistem dari gangguan-gangguan luar, baik selama di bumi, pada saat proses peluncuran (di dalam Roket), maupun pada saat di orbit.

Roket saat akan terbang menggunakan sayap untuk mendapatkan gaya angkat yang sebanding dengan berat total roket tersebut. Selain itu roket dilengkapi dengan fin (sirip) atau ekor yang berguna sebagai penyeimbang dari ketidakstabilan dinamik pada roketnya. Perbedaan fungsi antara sirip dengan sayap, dimana gaya angkat sirip digunakan sebagai pemulih keseimbangan roket yang berporos pada pusat gaya (titik berat) roket, sedangkan gaya angkat sayap digunakan untuk mengimbangi berat roket (Sofyan, et al, 1994). Bentuk penampang sirip ada beberapa macam jenisnya, tergantung dari bahan dasar pembuatan paduaannya. Dimana spesifikasi bahan paduan logam yang lebih ringan massanya misalkan paduan alumunium 7075, gaya angkat sayap digunakan untuk mengimbangi berat roket, sedangkan yang digunakan akan berpengaruh terhadap tingkat kesulitan dalam proses pabrikasi sirip tersebut. Salah satu cara untuk pembuatan paduan adalah metalurgi butiran.

Dalam penelitian Martin Djamin dan Budiarto mengatakan bahwa pemaduan CuNiAl dilakukan dengan menggunakan teknik metalurgi butiran dengan variasi waktu penuaan terhadap strukturmikro, densitas, dan kekerasan. Dimana proses metalurgi butiran merupakan proses untuk membentuk paduan tersebut. Keunggulan dari proses ini agar dicapai pembentukan butir yang halus, sehingga kemungkinan terjadinya retak antar butir (granular cracking) ketika deformasi dapat dihindarkan dan terdapat hubungan yang signifikan antara waktu penuaan dengan densitas dan kekerasan paduan CuNiAl dimana makin lama waktu penuaan, densitas dan kekerasan meningkat (Djamin \& Budiarto, 1999). Juga peneliti lainnya Bambang suhendar,dkk mengatakan bahwa pembuatan paduan ingat bentuk $\mathrm{Cu}-14 \% \mathrm{Al}-3-$ $4 \% \mathrm{Ni}$ dengan proses metalurgi Butiran dan peleburan dalam tungku pemanas listrik pada suhu 
$1.1000 \mathrm{C}$ telah berhasil membentuk martensite tipe $2 \mathrm{H}\left(\mathrm{\gamma} 1^{\prime}\right)$ dan tipe $18 \mathrm{R}\left(\beta 1^{\prime}\right)$. Pada sampel \#4, yang dilebur selama 30 menit, ditemukan struktur martensite yang tegas, padat, dan tidak berpori. Adanya puncak reaksi endotermal di suhu $150 \mathrm{C}$ pada kurva termogram (DSC) secara tidak langsung menunjukkan bahwa transformasi martensitik, yang menjadi karakteristik efek ingat bentuk, telah terjadi (Suhendar, et al, 2006).

Aluminium atau aluminium mempunyai struktur kubik berpusat muka (FCC), bilangan koordinasi struktur ini 12 dan dalam 1 unit sel terdapat 4 atom yang terletak pada posisi $000,0 \mathrm{y}$ j, j 0 j dan j y0. Parameter kisi struktur aluminium pada temperatur $20^{\circ} \mathrm{C}$ adalah $4,0490 \mathrm{~A}^{\circ}$. Aluminium mempunyai sifat mekanik yang rendah.

Tabel 1. Sifat Fisis Aluminium

\begin{tabular}{ll}
\hline Titik Leleh & $660^{\circ} \mathrm{C}$ \\
\hline Struktur Kristal & FCC \\
\hline Kerapatan relatif & $2,2 \times 10^{3} \mathrm{~kg} / \mathrm{m}^{3}$ \\
\hline Kuat Tarik Maksimum & $45 \times 10^{6} \mathrm{~N} / \mathrm{m}^{2}$ \\
\hline Modulus Spesifik & $26 \mathrm{Gpa}$ \\
\hline Panas Jenis Rata-rata $\left(0^{\circ} \mathrm{C}-100^{\circ} \mathrm{C}\right)$ & $9,7 \mathrm{~J} / \mathrm{kg}{ }^{\circ} \mathrm{K}$ \\
\hline Konduktivitas Panas $\left(20^{\circ} \mathrm{C}-100^{\circ} \mathrm{C}\right)$ & $238 \mathrm{~W} / \mathrm{m}^{\circ} \mathrm{K}$ \\
\hline Koef. Ekspansi Panas $\left(0^{\circ} \mathrm{C}-100^{\circ} \mathrm{C}\right)$ & $23,5 \times 10^{*} \mathrm{VK}$ \\
\hline Resistivitas Listrik $\left(20^{\circ} \mathrm{C}\right)$ & $2,67 \times 10^{* *} \mathrm{fl} . \mathrm{m}$ \\
\hline Angka Kekerasan Vickers & $140 \mathrm{~s} / \mathrm{d} 300 \mathrm{MN} / \mathrm{m}^{2}$ \\
\hline
\end{tabular}

Paduan Aluminium adalah campuran dari bahan utama aluminium dengan tambahan unsur-unsur pemadu dalam jumlah kecil. Tujuan penambahan unsur-unsur pemadu adalah untuk meningkatkan kekuatan, kekerasan, tahan korosi, meningkatkan laju alir pada saat pengecoran. Peningkatan kekuatan dan kekerasan paduan aluminium dengan memberikan heat treatment (perlakuan panas) terhadap komponen (part) paduan aluminium pasca pengecoran atau setelah pembentukan.

Berdasarkan pengelompokannya paduan aluminium dibagi dua kelompok, yaitu ada yang mampu ditingkatkan sifat mekaniknya (kekuatan, kekerasan) dengan memberikan perlakuan panas dan yang tidak. Pada tabel dibawah ini diperlihatkan dengan tanda bintang $\left(^{*}\right)$ untuk paduan yang heat treatable (mampu ditingkatkan sifat mekaniknya dengan memberikan efek perlakuan panas. 
Submitted: 7 Nopember 2019; Revised: 21 Nopember 2019; Accepted: 5 Desember 2019; Published: 25 Januari 2020

\begin{tabular}{cc}
\hline Seri & Paduan Aluminium \\
\hline $1 \mathrm{xxx}$ & $99 \%$ berat aluminium \\
\hline $2 \mathrm{xxx}$ & $\mathrm{Al}-\mathrm{Cu}\left(^{*}\right)$ \\
\hline $3 \mathrm{xxx}$ & $\mathrm{Al}-\mathrm{Mn}$ \\
\hline $4 \mathrm{xxx}$ & $\mathrm{Al}-\mathrm{Si}$ \\
\hline $5 \mathrm{xxx}$ & $\mathrm{Al}-\mathrm{Mg}$ \\
\hline $6 \mathrm{xxx}$ & $\mathrm{Al}-\mathrm{Mg}-\mathrm{Si}\left(^{*}\right)$ \\
\hline $7 \mathrm{xxx}$ & $\mathrm{Al}-\mathrm{Zn}\left({ }^{*}\right)$ \\
\hline
\end{tabular}

\section{Perlakuan Panas (Heat Treatment) pada Paduan Aluminium}

Proses T6 dilakukan dengan cara memanaskan bahan paduan butiran pada suhu pelarutan dan dilanjutkan pendinginan secara celup cepat pada media air. Kemudian dilakukan pemanasan penuaan dengan waktu yang ditentukan. Skema proses T6 dapat dlihat pada Gambar 1.

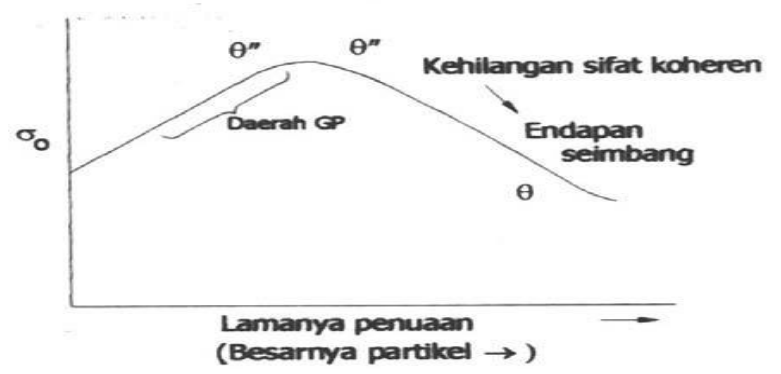

Gambar 1. Skema perlakuan panas T6 pada paduan alumunium.

\section{Analisis X-Ray Diffraction (XRD)}

Teknik X-Ray Diffraction (XRD) berperan penting dalam proses analisis padatan kristalin. XRD adalah metode karakterisasi yang digunakan untuk mengetahui ciri utama kristal, seperti parameter kisi dan tipe struktur. Selain itu, juga dimanfaatkan untuk mengetahui rincian lain seperti susunan berbagai jenis atom dalam kristal, kehadiran cacat, orientasi, dan cacat kristal (Smallman \& Bishop, 2000).

Sinar-X pertama kali ditemukan oleh Wilhelm Rontgen pada tahun 1895. Sinar-X merupakan gelombang elektromagnetik dengan panjang gelombang $(\lambda \approx 0,1 \mathrm{~nm})$ yang lebih pendek dibanding gelombang cahaya $(\lambda=400-800 \mathrm{~nm}$ ) (Smallman \& Bishop, 2000). Panjang gelombang sinar-X ini merupakan dasar digunakannya teknik difraksi sinar-X (X-Ray Difraction) untuk mengetahui struktur mikroskopis suatu bahan. 


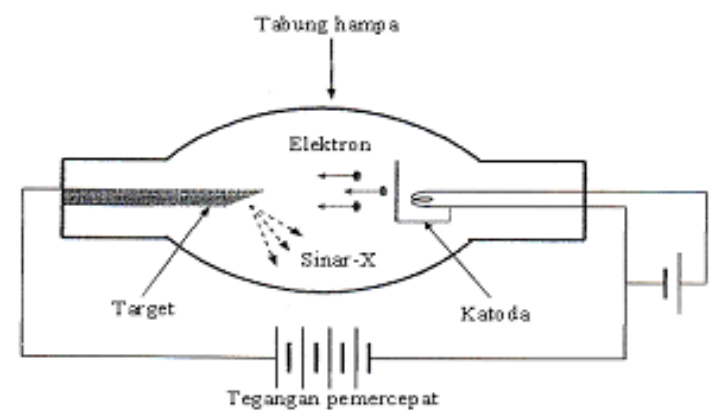

Gambar 2. Diagram Sinar-X

Jika sinar-X mengenai suatu bahan, maka intensitas sinar yang ditransmisikan akan lebih rendah dibandingkan dengan intensitas sinar yang datang, karena terjadi penyerapan oleh bahan dan penghamburan atom-atom dalam bahan tersebut. Berkas difraksi diperoleh dari berkas sinar-X yang saling menguatkan karena mempunyai fase yang sama. Untuk berkas sinar-X yang mempunyai fase berlawanan maka akan saling menghilangkan. Syarat yang harus dipenuhi agar berkas sinar-X yang dihamburkan merupakan berkas difraksi maka dapat dilakukan perhitungan secara matematis sesuai dengan hukum Bragg.

Menurut Bragg berkas yang terdifraksi oleh kristal terjadi jika pemantulan oleh bidang sejajar atom menghasilkan interferensi konstruktif. Pemantulan sinar-X oleh sekelompok bidang paralel dalam kristal pada hakekatnya merupakan gambaran dari difraksi atom-atom kristal. Difraksi atom-atom kristal sebagai pantulan sinar-X oleh sekelompok bidang-bidang paralel dalam kristal seperti terlihat pada Gambar 3. Arah difraksi sangat ditentukan oleh geometri kisi, yang bergantung pada orientasi dan jarak antar bidang kristal.

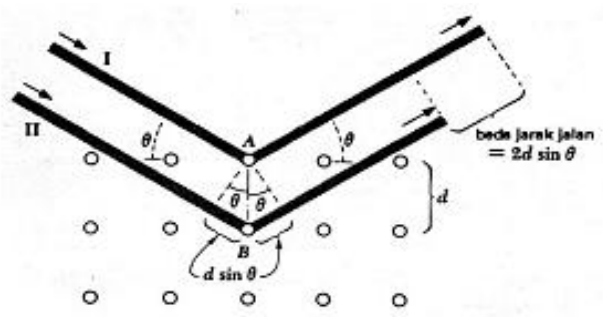

Gambar 3. Difraksi Bragg

Gambar 3 menunjukkan seberkas sinar mengenai atom A pada bidang pertama dan B pada bidang berikutnya. Jarak antara bidang $A$ dengan bidang $B$ adalah $d$, sedangkan a adalah sudut difraksi. Berkas-berkas tersebut mempunyai panjang gelombang $\lambda$, dan jatuh pada bidang kristal dengan jarak $d$ dan sudut $\theta$. Agar mengalami interferensi konstruktif, kedua berkas tersebut harus memiliki beda jarak $n \lambda$. Sedangkan beda jarak lintasan kedua berkas adalah $2 \mathrm{~d} \sin \theta$. Interferensi konstruktif terjadi jika beda jalan sinar adalah kelipatan bulat panjang gelombang $\lambda$, sehingga dapat dinyatakan dengan persamaan: $n \lambda=2 d \sin \theta$

Pernyataan ini adalah hukum Bragg. Pemantulan Bragg dapat terjadi jika $\leq 2 \mathrm{~d}$, karena itu tidak dapat menggunakan cahaya kasat mata, dengan $n$ adalah bilangan bulat $=1,2,3, \ldots[5]$. Arah berkas yang dipantulkan oleh atom dalam kristal ditentukan oleh geometri dari kisi kristal 
Submitted: 7 Nopember 2019; Revised: 21 Nopember 2019; Accepted: 5 Desember 2019; Published: 25 Januari 2020

yang bergantung pada orientasi dan jarak bidang kristal. Suatu kristal yang memiliki simetri kubik $\left(a=b=c, \alpha=\beta=y=90^{\circ}\right.$ ) dengan ukuran parameter kisi, $a=b=c$, maka sudut-sudut berkas yang didifraksikan dari bidang-bidang kristal (hkl) dapat dihitung dengan rumus jarak antarbidang sebagai berikut:

$$
\frac{1}{d^{2}}=\frac{h^{2}+k^{2}+l^{2}}{a^{2}}
$$

Struktur kristal ditentukan dengan difraksi sinar-X. Jarak interplanar dapat dihitung hingga empat atau lebih angka signifikan dengan mengukur sudut difraksi. Ini merupakan dasar untuk menentukan jarak interatomik dan menghitung jari-jari [6]. Penentuan orientasi kristal dilakukan dengan mengamati pola berkas difraksi sinar-X yang dipantulkan oleh kristal. Untuk $X R D$, pola difraksi diamati sebagai fungsi sudut $2 \theta$. Pola difraksi yang terjadi kemudian dibandingkan dengan JCPDS sebagai data standar.

\section{Kekerasan Bahan dengan Skala Vickers}

Kekerasan merupakan ukuran ketahanan material terhadap deformasi tekan. Deformasi yang terjadi dapat berupa kombinasi perilaku elastis dan plastis. Pada permukaan dari dua komponen yang saling bersinggungan dan bergerak satu terhadap lainnya akan terjadi deformasi elastis maupun plastis. Deformasi elastis kemungkinan terjadi pada permukaan yang keras, sedangkan deformasi plastis terjadi pada permukaan yang lebih lunak. Efek deformasi tergantung pada kekerasan permukaan material.

Uji kekerasan vickers menggunakan indentor piramida intan yang pada dasarnya berbentuk bujur sangkar. Besar sudut antar permukaan piramida intan yang saling berhadapan adalah $136^{\circ}$. Nilai ini dipilih karena mendekati sebagian besar nilai perbandingan yang diinginkan antar diameter lekukan dan diameter bola penumbuk pada uji kekerasan Brinell (Dieter, 1988).

Angka kekerasan vickers didefinisikan sebagai beban dibagi luas permukaan lekukan. Pada prakteknya. Luas ini dihitung dari pengukuran mikroskopik panjang diagonal jejak. VHN dapat ditentukan dari persamaan berikut:

$$
\begin{aligned}
& \text { VHN }=\frac{2 P \sin \frac{\Theta}{2}}{d^{2}}=\frac{(1,854) P}{d^{2}} \\
& \text { Keterangan: } \\
& \begin{array}{ll}
P \quad=\text { beban yang digunakan }(\mathrm{kg}) \\
\mathrm{d} \quad=\text { panjang diagonal rata-rata }(\mathrm{mm}) \\
\Theta \quad=\text { sudut antara permukaan intan yang berhadapan }=136^{\circ}
\end{array}
\end{aligned}
$$

Karena jejak yang dibuat dengan penekanan piramida serupa secara geometris dan tidak terdapat persoalan mengenai ukuranya, maka VHN tidak tergantung kepada beban. Pada 
umumnya hal ini dipenuhi, kecuali pada beban yang sangat ringan. Beban yang biasanya digunakan pada uji vickers berkisar antara 1 hingga $120 \mathrm{~kg}$. Tergantung pada kekerasan logam yang akan diuji.

\section{Prinsip kerja Scanning Electron Microscope (SEM) - Energy Dispersive X-ray (EDX).}

Scanning electron microscope (SEM) adalah salah satu jenis mikroskop electron yang menggunakan berkas elektron untuk menggambarkan bentuk permukaan dari sampel yang dianalisis. SEM memiliki resolusi yang lebih tinggi daripada optical microscope (OM). Hal ini disebabkan panjang gelombang de Broglie yang memiliki elektron lebih pendek daripada gelombang OM. Karena semakin kecil panjang gelombang yang digunakan maka semakin tinggi resolusi mikroskop. SEM memiliki resolusi yang lebih tinggi daripada OM. Resolusi yang mampu dihasilkan OM hanya $200 \mathrm{~nm}$, sedangkan resolusi yang dapat dihasilkan SEM mencapai $0.1-0.2 \mathrm{~nm}$.

Prinsip kerja dari SEM adalah dengan menggambarkan permukaan benda atau material dengan berkas elektron yang dipantulkan dengan energi tinggi. Permukaan material yang disinari atau terkena berkas elektron akan memantulkan kembali berkas elektron atau dinamakan berkas elektron sekunder ke segala arah. Tetapi dari semua berkas elektron yang dipantulkan terdapat satu berkas elektron berintensitas tertinggi yang dipantulkan oleh sampel yang akan dianalisis.

Pengamatan sampel dilakukan dengan menembakkan berkas elektron yang berintensitas tertinggi ke permukaan sampel, kemudian scan keseluruh permukaan material pengamatan. Karena luasnya daerah pengamatan, dapat dibatasi lokasi yang akan diamati dengan melakukan zoom-in atau zoom-out. Dengan memanfaatkan berkas pantulan dari benda tersebut maka informasi dapat diketahui dengan menggunakan program pengolahan citra yang terdapat di dalam komputer. Prinsip kerja dari SEM ditunjukkan pada Gambar 4.

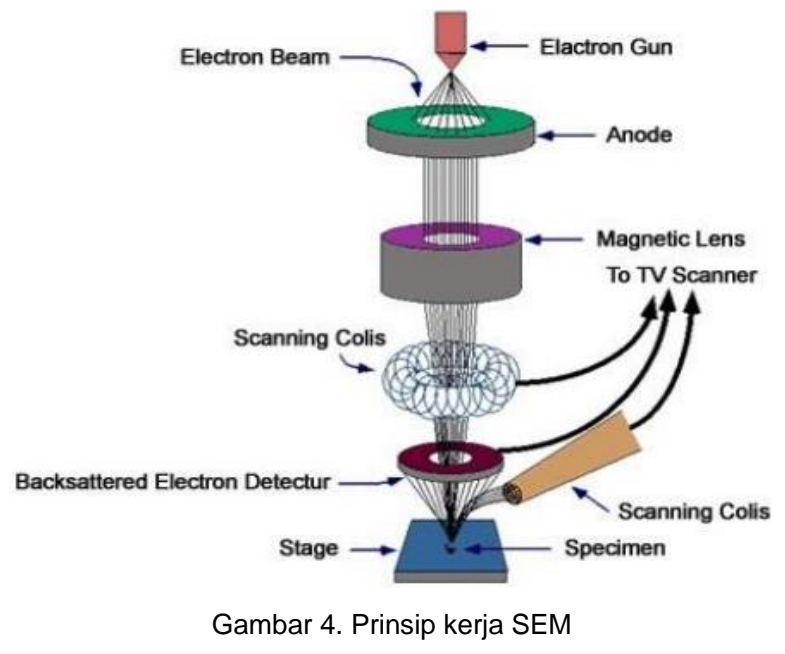

Prinsip kerja yang ditunjukkan pada Gambar 2.4. adalah sebuah pistol electron memproduksi sinar elektron dan dipercepat dengan anoda. Lensa magnetic memfokuskan 
Submitted: 7 Nopember 2019; Revised: 21 Nopember 2019; Accepted: 5 Desember 2019; Published: 25 Januari 2020

elektron menuju ke sampel. Sinar elektron yang terfokus memindai (scan) keseluruhan sampel dengan diarahkan oleh koil pemindai. Ketika electron mengenai sampel maka sampel akan mengeluarkan elektron baru yang akan diterima oleh detektor dan dikirim ke monitor (CRT).

Ada beberapa sinyal yang penting yang dihasilkan oleh SEM. Dari pantulan inelastis didapatkan sinyal elektron sekunder dan karakteristik sinar $\mathrm{X}$, sedangkan dari pantulan elastis didapatkan sinyal backscattered electron. Perbedaan gambar dari sinyal elektron sekunder dengan backscattered adalah sebagai berikut: elektron sekunder menghasilkan topografi dari benda yang dianalisa, permukaan yang tinggi berwarna lebih cerah dari permukaan rendah. Sedangkan back scattered electron memberikan perbedaan berat molekul dari atom - atom yang menyusun permukaan, atom dengan berat molekul tinggi akan berwarna lebih cerah daripada atom dengan berat molekul rendah.

Untuk mengetahui komposisi kimia pada permukaan sampel, sebagian besar alat SEM dilengkapi dengan kemampuan energy dispersive $x$-ray (EDX). EDX dihasilkan dari sinar-X, yaitu dengan menembakkan sinar-X pada posisi yang ingin diketahui komposisinya. Setelah ditembakkan pada posisi yang diinginkan maka akan muncul puncak - puncak tertentu yang mewakili suatu unsur yang terkandung. Dengan EDX juga bisa membuat elemental mapping (pemetaan elemen) dengan memberikan warna berbeda - beda dari masing - masing elemen di permukaan sampel. EDX bisa digunakan untuk menganalisa secara kuantitatif dari persentase masing - masing elemen.

SEM-EDX dapat memberikan informasi tentang topografi, morfologi, komposisi dari sampel yang dianalisis. Topografi adalah kemampuan untuk menganalisa permukaan dan teksture. Morfologi adalah kemampuan untuk menganalisa bentuk dan ukuran dari benda sampel. Komposisi adalah kemampuan menganalisa komposisi dari permukaan benda secara kuantitatif dan kualitatif.

\section{Metode Penelitian}

Dilakukan proses T6 dimulai suhu $5700 \mathrm{C}$ untuk proses pelarutan ditahan selama 1 jam. Dilanjutkan celup cepat ke suhu ruang media air. Proses selanjutnya artificial aging (penuaan buatan) selama 1,4 , dan 20 jam pada suhu $210^{\circ} \mathrm{C}$. Setelah proses pendinginan, spesimen ini kemudian dilakukan proses metalografi (grinding, amplas, poles, etsa, dstnya).

Karakterisasi hasil pembuatan/sintesa paduan Al-7075 antara lain: Pengujian dan pengamatan struktur mikro, komposisi unsur kimia secara kualitatif dan kuantitatif dengan alat SEM-EDXS; serta pengujian struktur kristal, besar ukuran kristal, regangan kisi dan kerapatan dislokasi Kristal dengan XRD.

\section{Hasil dan Pembahasan}

Data yang diperoleh dari hasil pengujian perlakuan panas terhadap Aluminium 7075 dengan menggunakan metode XRD sebagai berikut. 
Analisis Ukuran Kristal, Densitas Dislokasi, dan Regangan Kisi Mikro sebelum dan sesudah dilakukan perlakuan panas (Solid Solution).

Tabel 3. Hasil analisis XRD pada paduan Aluminium 7075.

\begin{tabular}{llllll}
\hline & & $\beta$ & $D$ & $\rho$ & $\varepsilon$ \\
\hline No Puncak & $\Theta\left({ }^{\circ}\right)$ & $\begin{array}{l}2 \Theta\left(^{\circ}\right) \\
1\end{array}$ & $\begin{array}{l}\text { Ukuran } \\
(\mathrm{nm})\end{array}$ & $\begin{array}{l}\text { Kristal } \\
\text { (Densitas } \\
\text { Dislokasi) }\end{array}$ & $\begin{array}{l}\text { (Regangan } \\
\text { Kisi) }\end{array}$ \\
\hline 2 & 38.1468 & 0.1791 & 8.1914 & 0.01490 & $12.95 \%$ \\
\hline 3 & 37.9993 & 0.1872 & 7.8335 & 0.01630 & $13.59 \%$ \\
\hline 4 & 44.3749 & 0.1023 & 14.6375 & 0.00467 & $6.27 \%$ \\
\hline 5 & 64.6686 & 0.2184 & 7.5137 & 0.01771 & $8.63 \%$ \\
\hline & 44.2552 & 0.1560 & 9.5948 & 0.01086 & $9.59 \%$ \\
\hline
\end{tabular}

Tabel 4. Hasil analisis XRD Al 7075 dengan perlakuan panas (Solid Solution pada suhu $570^{\circ} \mathrm{C}$ selama 1 jam).

\begin{tabular}{cccccc}
\hline No & & $\beta$ & $\mathrm{D}$ & $\rho$ & $\varepsilon$ \\
\hline Puncak & $2 \Theta\left(^{\circ}\right)$ & $\begin{array}{c}\text { FWHM } \\
2 \Theta\left(^{\circ}\right)\end{array}$ & $\begin{array}{c}\text { Ukuran } \\
\text { Kristal } \\
(\mathrm{nm})\end{array}$ & $\begin{array}{c}\text { (Densitas } \\
\text { Dislokasi) }\end{array}$ & $\begin{array}{c}\text { (Regangan } \\
\text { Kisi) }\end{array}$ \\
\hline 1 & 44.0337 & 0.2303 & 6.4942 & 0.02371 & $14.24 \%$ \\
\hline 2 & 37.8565 & 0.2814 & 5.2090 & 0.03686 & $20.51 \%$ \\
\hline 3 & 64.469 & 0.2047 & 8.0077 & 0.01559 & $8.12 \%$ \\
\hline 5 & 77.5643 & 0.1560 & 11.4018 & 0.00769 & $4.85 \%$ \\
\hline & 77.8448 & 0.1791 & 9.9508 & 0.01010 & $5.54 \%$ \\
\hline \multirow{5}{*}{$\begin{array}{c}\text { Rata - } \\
\text { Rata }\end{array}$} & 8.21270 & 0.01879 & $10.65 \%$ \\
\hline
\end{tabular}

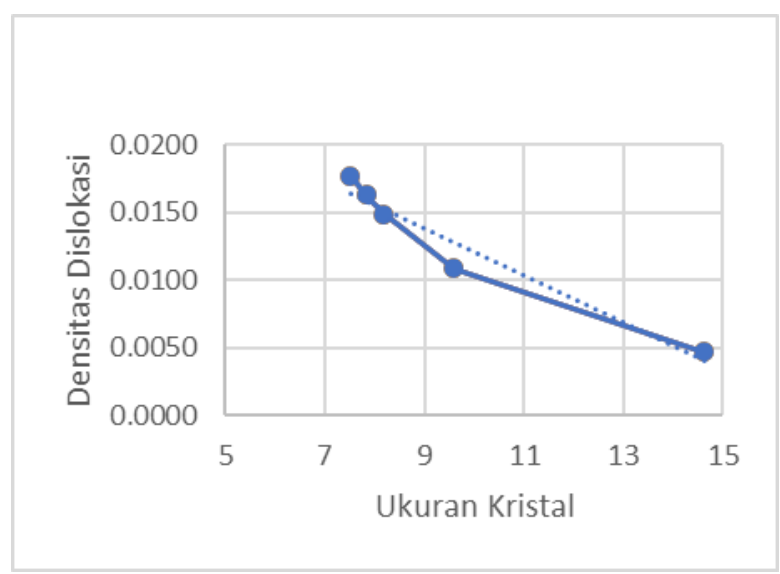

Gambar 5. Grafik hasil analisis XRD paduan Aluminium 7075 


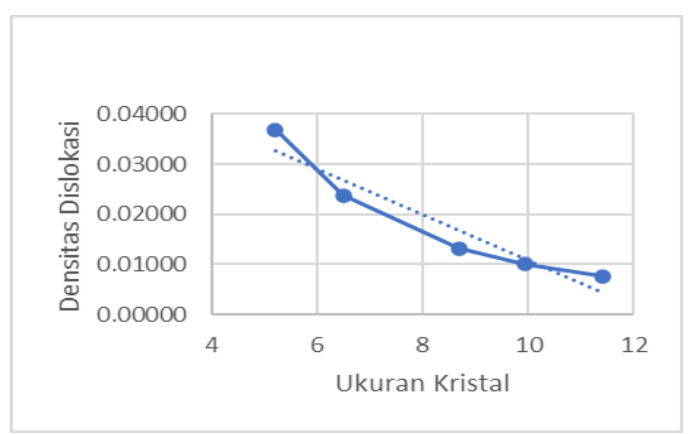

Gambar 6. Grafik hasil analisis XRD paduan Aluminium 7075 dengan perlakuan panas (Solid Solution pada suhu $570^{\circ} \mathrm{C}$ selama 1 jam).

Dari Tabel 3 dan Tabel 4 menunjukkan bahwa ada pengaruh material paduan Al7075 sebelum dan sesudah perlakuan panas (Solid Solution) terhadap ukuran kristal (D), regangan kisi $(\varepsilon)$, dan kerapatan dislokasi $(\rho)$. Dimana dengan perlakuan panas diatas $500{ }^{\circ} \mathrm{C}$ menyebabkan penurunan densitas dislokasi yang diikuti dengan bertambahnya regangan kisi.

\section{Analisis Ukuran Kristal, Kerapatan Dislokasi, dan Regangan Kisi Mikro sesudah pemanasan penuaan (artificial aged)}

Tabel 5. Hasil analisis XRD AI 7075 dengan perlakuan panas (Solid Solution pada suhu $570^{\circ} \mathrm{C}$ selama 1 jam).

\begin{tabular}{cccccc}
\hline & & $\beta$ & $\mathrm{D}$ & $\rho$ & $\varepsilon$ \\
\hline $\begin{array}{c}\text { No } \\
\text { Puncak }\end{array}$ & $2 \Theta\left(^{\circ}\right)$ & FWHM $2 \Theta\left(^{\circ}\right)$ & $\begin{array}{c}\text { Ukuran } \\
\text { Kristal } \\
(\mathrm{nm})\end{array}$ & $\begin{array}{c}\text { (Densitas } \\
\text { Dislokasi) }\end{array}$ & $\begin{array}{c}\text { (Regangan } \\
\text { Kisi) }\end{array}$ \\
\hline 1 & 44.3332 & 0.307 & 4.8769 & 0.04205 & $18.84 \%$ \\
\hline 2 & 38.1362 & 0.3326 & 4.4108 & 0.05140 & $24.06 \%$ \\
\hline 3 & 77.8076 & 0.2047 & 8.7041 & 0.01320 & $6.34 \%$ \\
\hline 4 & 64.6803 & 0.2558 & 6.4155 & 0.02430 & $10.10 \%$ \\
\hline 5 & 81.9608 & 0.3582 & 5.1274 & 0.03804 & $10.31 \%$ \\
\hline
\end{tabular}

Tabel 6. Hasil analisis XRD Al 7075 dengan perlakuan panas (Solid Solution pada suhu $570^{\circ} \mathrm{C}$ selama 4 jam).

\begin{tabular}{cccccc}
\hline & & $\beta$ & $\mathrm{D}$ & $\rho$ & $\varepsilon$ \\
\hline $\begin{array}{c}\text { No } \\
\text { Puncak }\end{array}$ & $2 \Theta\left(^{\circ}\right)$ & FWHM 2 $\left(^{\circ}\right)$ & $\begin{array}{c}\text { Ukuran } \\
\text { Kristal } \\
(\mathrm{nm})\end{array}$ & $\begin{array}{c}\text { (Densitas } \\
\text { Dislokasi) }\end{array}$ & $\begin{array}{c}\text { (Regangan } \\
\text { Kisi) }\end{array}$ \\
\hline 1 & 37.9215 & 0.3838 & 3.8199 & 0.06853 & $27.93 \%$ \\
\hline 2 & 44.1574 & 0.4349 & 3.4405 & 0.08448 & $26.80 \%$ \\
\hline 3 & 77.7305 & 0.2808 & 6.3417 & 0.02486 & $8.71 \%$ \\
\hline 4 & 77.9401 & 0.1872 & 9.5267 & 0.01102 & $5.79 \%$ \\
\hline 5 & 81.931 & 0.2496 & 7.3567 & 0.01848 & $7.19 \%$ \\
\hline & & Rata - Rata & 6.09709 & 0.04147 & $15.28 \%$ \\
\hline
\end{tabular}


Tabel 7. Hasil analisis XRD Al 7075 dengan perlakuan panas (Solid Solution pada suhu $570^{\circ} \mathrm{C}$ selama 20 jam).

\begin{tabular}{cccccc}
\hline & & $\beta$ & $\mathrm{D}$ & $\rho$ & $\varepsilon$ \\
\hline $\begin{array}{c}\text { No } \\
\text { Puncak }\end{array}$ & $2 \Theta\left(^{\circ}\right)$ & FWHM 2 $\left(^{\circ}\right)$ & $\begin{array}{c}\text { Ukuran } \\
\text { Kristal } \\
(\mathrm{nm})\end{array}$ & $\begin{array}{c}\text { (Densitas } \\
\text { Dislokasi) }\end{array}$ & $\begin{array}{c}\text { (Regangan } \\
\text { Kisi) }\end{array}$ \\
\hline 1 & 43.7648 & 0.1248 & 11.9727 & 0.00698 & $7.77 \%$ \\
\hline 2 & 43.8831 & 0.0624 & 23.9554 & 0.00174 & $3.87 \%$ \\
\hline 3 & 37.5347 & 0.1279 & 11.4496 & 0.00763 & $9.41 \%$ \\
\hline 4 & 77.354 & 0.156 & 11.3851 & 0.00771 & $4.87 \%$ \\
\hline 5 & 64.2049 & 0.0936 & 17.4873 & 0.00327 & $3.73 \%$ \\
\hline & & Rata - Rata & 15.25000 & 0.00547 & $5.93 \%$ \\
\hline
\end{tabular}

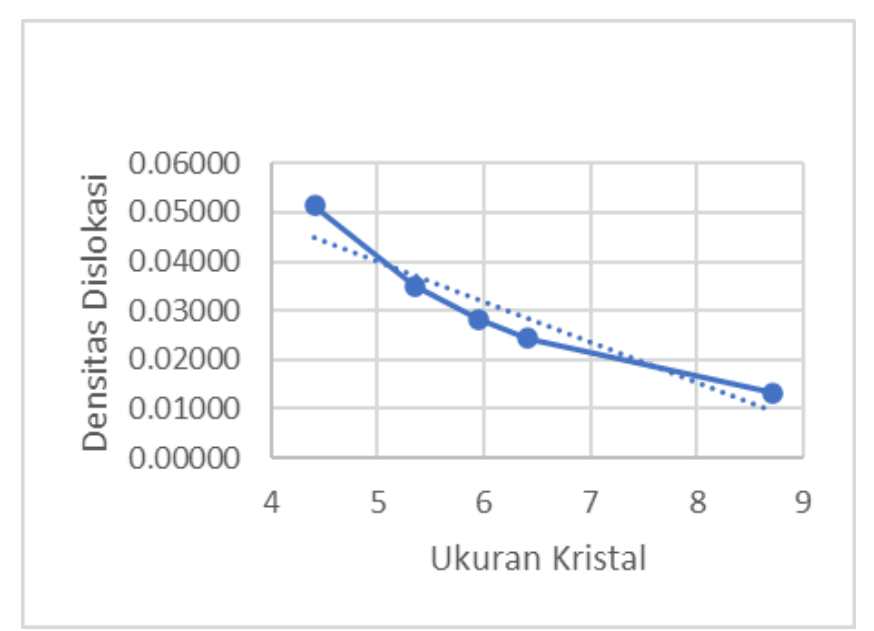

Gambar 7. Grafik hasil analisis XRD paduan Aluminium 7075 sesudah penuaan buatan (artificial aged) selama 1 jam.

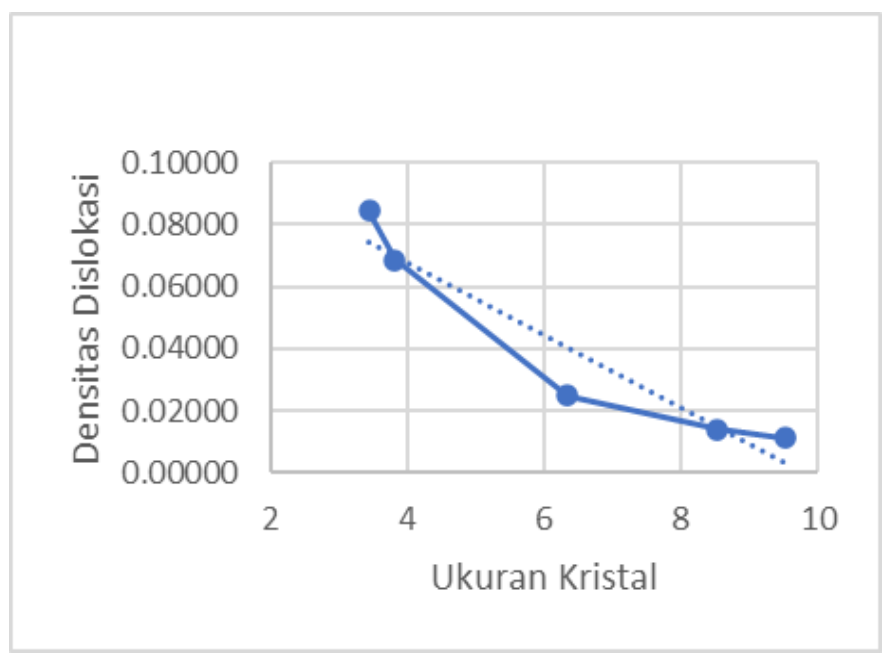

Gambar 8. Grafik hasil analisis XRD paduan Aluminium 7075 sesudah penuaan buatan (artificial aged) selama 4 jam. 


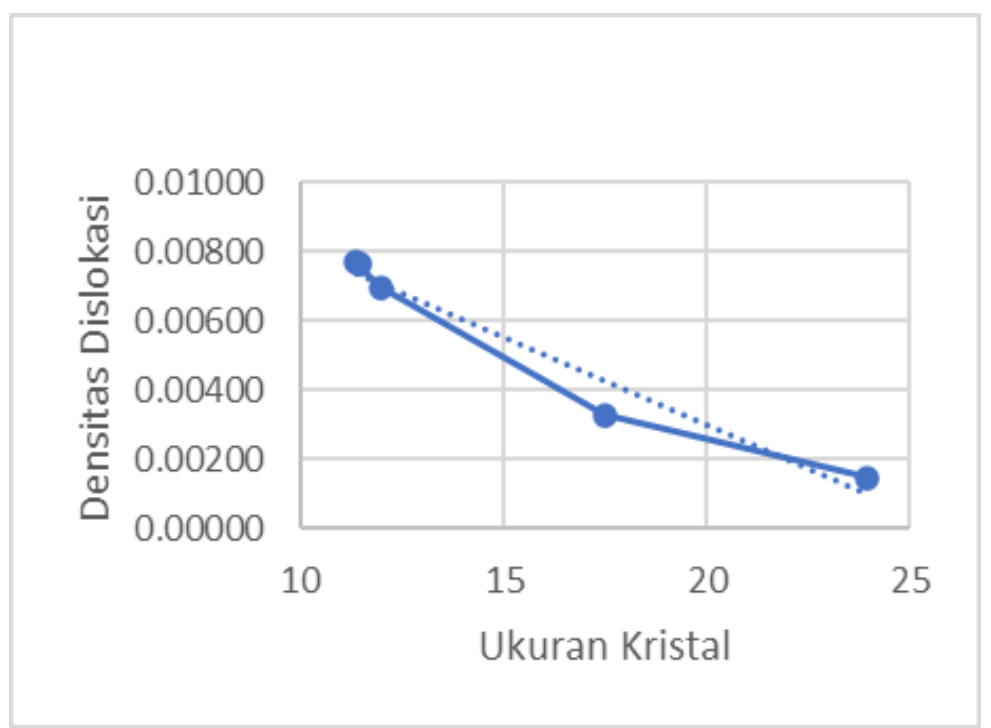

Gambar 9. Grafik hasil analisis XRD paduan Aluminium 7075 sesudah penuaan buatan (artificial aged) selama 20 jam.

Ukuran kristal, dan hubungan hasil regangan kisi dan kerapatan dislokasi terhadap variasi waktu pemanasan penuaan buatan (artificial aged) ditunjukkan pada Tabel 5-7 dan Gambar 7-9. Perlakuan panas penuaan buatan pada suhu $210^{\circ} \mathrm{C}$ menyebabkan penurunan Ukuran Kristal dari perlakuan panas (Solid Solution) pada suhu $570^{\circ} \mathrm{C}$ yang diikuti dengan bertambahnya Ukuran Kristal seiring dengan lamanya waktu pemanasan penuaan buatan. Sedangkan densitas dislokasi dan regangan kisi meningkat selama periode waktu pemanasan 1 jam dan 4 jam, lalu pada waktu 20 jam mengalami penurunan densitas dislokasi serta regangan kisi.

\section{Analisis Kekuatan dari Bahan Al-7075.}

Pengujian kekerasan dilakukan dengan cara Hardness Vickers skala HV. Indentor yang dipakai adalah pyramidal diamond dengan besar sudut antar permukaan pyramidal diamond yang saling berhadapan adalah $136^{\circ}$. Alat yang dipakai untuk pengujian adalah Microhardness Tester merk Future Tech FM800. Standar yang digunakan untuk pengujian mengacu pada ASTM E92.

Uji kekerasan diberikan terhadap 5 buah sampel uji Al 7075, 1 buah sampel uji Al7075 tanpa perlakuan panas, 1 buah sample

uji dengan perlakuan panas (Solid Solution) pada suhu $570^{\circ} \mathrm{C}$ selama 1 jam, 1 buah sampel uji dengan perlakuan panas penuaan buatan (T6) pada suhu $210^{\circ} \mathrm{C}$ selama 1 jam, 1 buah sampel uji dengan perlakuan panas penuaan buatan (T6) pada suhu $210^{\circ} \mathrm{C}$ selama 4 jam, 1 buah sampel uji dengan perlakuan panas penuaan buatan (T6) pada suhu $210^{\circ} \mathrm{C}$ selama 20 jam. Hasil pengujian ditunjukkan pada Tabel 8. 
Tabel 8. Hasil pengujian kekerasan skala Hardness Vickers pada Al 7075.

\begin{tabular}{|c|c|c|c|c|c|}
\hline Kode Sampel & Beban & Titik $^{*}$ & Diagonal $1(\mu \mathrm{m})$ & Diagonal $2(\mu \mathrm{m})$ & $\begin{array}{c}\text { Nilai Kekerasan Vickers } \\
(\mathrm{HV})\end{array}$ \\
\hline \multirow{3}{*}{ A1 } & $4,903 \mathrm{~N} /$ & 1 & 106,06 & 102,50 & 85,3 \\
\hline & \multirow[t]{2}{*}{$0,5 \mathrm{kgF}$} & 2 & 90,12 & 115,27 & 82,9 \\
\hline & & Rata-rata & 98,09 & 108,885 & 84,1 \\
\hline \multirow{3}{*}{ A2 } & $4,903 \mathrm{~N} /$ & 1 & 99,47 & 86,36 & 107,40 \\
\hline & \multirow[t]{2}{*}{$0,5 \mathrm{kgF}$} & 2 & 89,93 & 90,37 & 114,10 \\
\hline & & Rata-rata & 94,70 & 88,37 & 110,75 \\
\hline \multirow{3}{*}{ A3 } & \multirow{3}{*}{$\begin{array}{c}2,942 \mathrm{~N} / \\
0,5 \mathrm{kgF}\end{array}$} & 1 & 79,93 & 72,52 & 95,70 \\
\hline & & 2 & 74,22 & 72,21 & 103,80 \\
\hline & & Rata-rata & 77,08 & 72,37 & 99,75 \\
\hline \multirow{3}{*}{ A4 } & \multirow{3}{*}{$\begin{array}{c}2,942 \mathrm{~N} / \\
0,5 \mathrm{kgF}\end{array}$} & 1 & 67,36 & 62,82 & 131,30 \\
\hline & & 2 & 69,17 & 65,03 & 123,60 \\
\hline & & Rata-rata & 68,27 & 63,93 & 127,45 \\
\hline \multirow{3}{*}{ A5 } & \multirow{3}{*}{$\begin{array}{c}2,942 \mathrm{~N} / \\
0,5 \mathrm{kgF}\end{array}$} & 1 & 61,47 & 60,74 & 149,00 \\
\hline & & 2 & 59,49 & 66,23 & 140,80 \\
\hline & & Rata-rata & 60,48 & 63,49 & 144,90 \\
\hline
\end{tabular}

Keterangan:

* Jarak antar titik, acak.

A1 Al 7075 tanpa perlakuan panas.

A2 Al 7075 dengan perlakuan panas (Solid Solution).

A3 Al 7075 dengan perlakuan panas (T6) selama 1 jam.

A4 Al 7075 dengan perlakuan panas (T6) selama 4 jam.

A5 Al 7075 dengan perlakuan panas (T6) selama 20 jam.

Dari hasil pengamatan angka kekerasan rata-rata sampel uji Al 7075 yang mengalami perlakuan panas penuaan buatan (artificial aged) pada suhu $210^{\circ} \mathrm{C}$ dengan variasi waktu selama 1 jam, 4 jam dan 20 jam maka dibuat kurva angka kekerasan terhadap variasi waktu yang ditunjukkan pada gambar 10 .

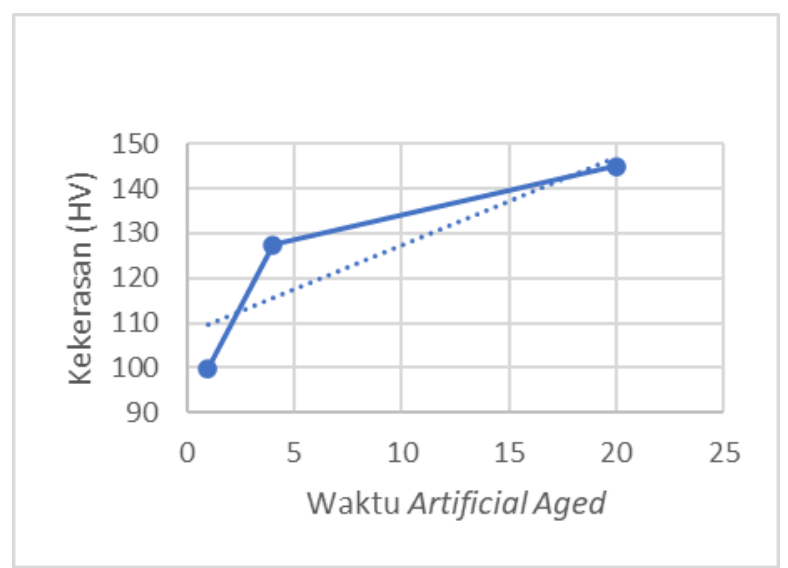

Gambar 10. Grafik angka kekerasan (HV) terhadap waktu Artificial Aged. 
Submitted: 7 Nopember 2019; Revised: 21 Nopember 2019; Accepted: 5 Desember 2019; Published: 25 Januari 2020

Dari hasil pengujian kekerasan dengan menggunakan skala Hardness Vickers, setelah 1 jam proses penuaan buatan dengan suhu $210^{\circ} \mathrm{C}$, bahan mengalami kenaikan nilai kekerasan dibandingkan bahan tanpa perlakuan panas sebesar $18,61 \%$ atau semula $84,1 \mathrm{HV}$ menjadi 99,75 HV. Nilai kekerasan tertinggi ada pada variasi waktu pemanasan selama 20 jam, dengan peningkatan sebesar $42,96 \%$ atau menjadi $144,9 \mathrm{HV}$.

Analisis Struktur Mikro dari Bahan Al 7075 dengan Scanning Electron Microscope (SEM).

Pengujian dilakuan terhadap 3 buah sampel uji, 1 buah sampel tanpa perlakuan panas, 1 buah sampel dengan perlakuan panas (Solid Solution), dan 1 buah sampel dengan perlakuan panas penuaan buatan (artificial aged). Pengujian dengan menggunakan Scanning Electron Microscope (SEM), masing-masing sampel dilakukan pengujian sebanyak 3 kali. Hasil pengujian SEM ditunjukkan pada gambar $11-13$.
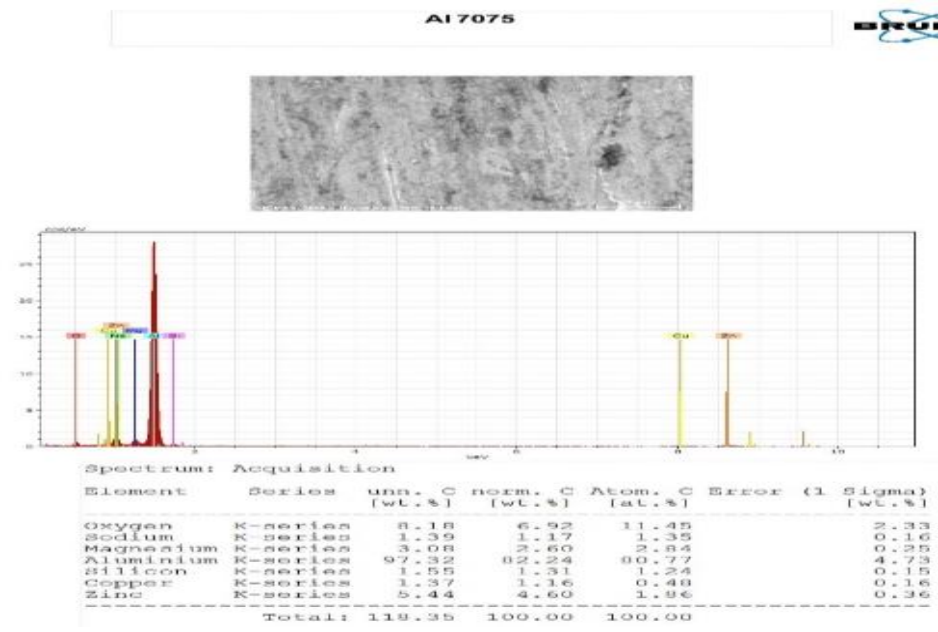

Sumber: Hasil Penelitian (2020)

Gambar 11. Pengujian SEM pada bahan Al 7075 tanpa perlakuan panas.

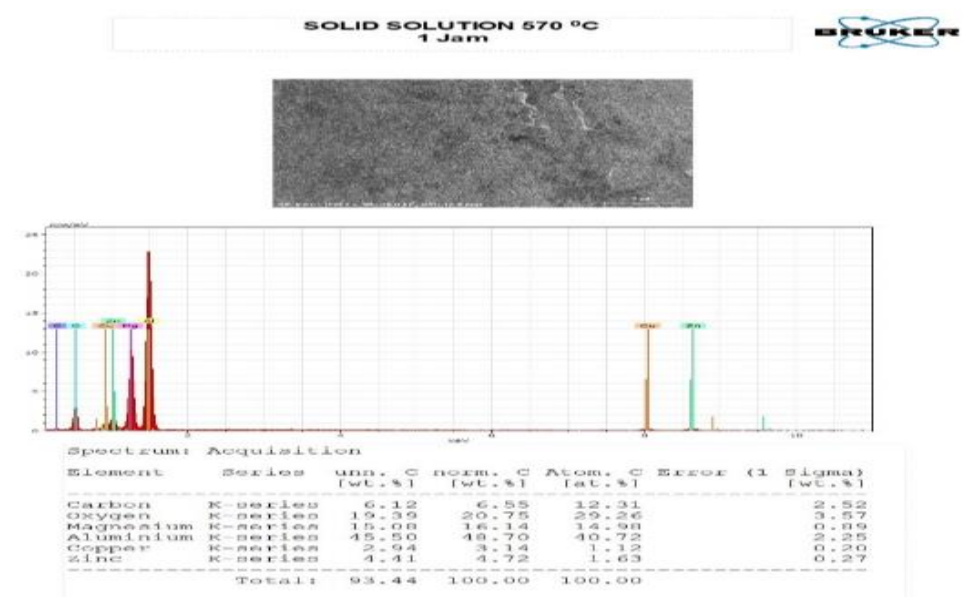

Sumber: Hasil Penelitian (2020)

Gambar 12. Pengujian SEM pada bahan Al 7075 dengan perlakuan panas (Solid Solution). 

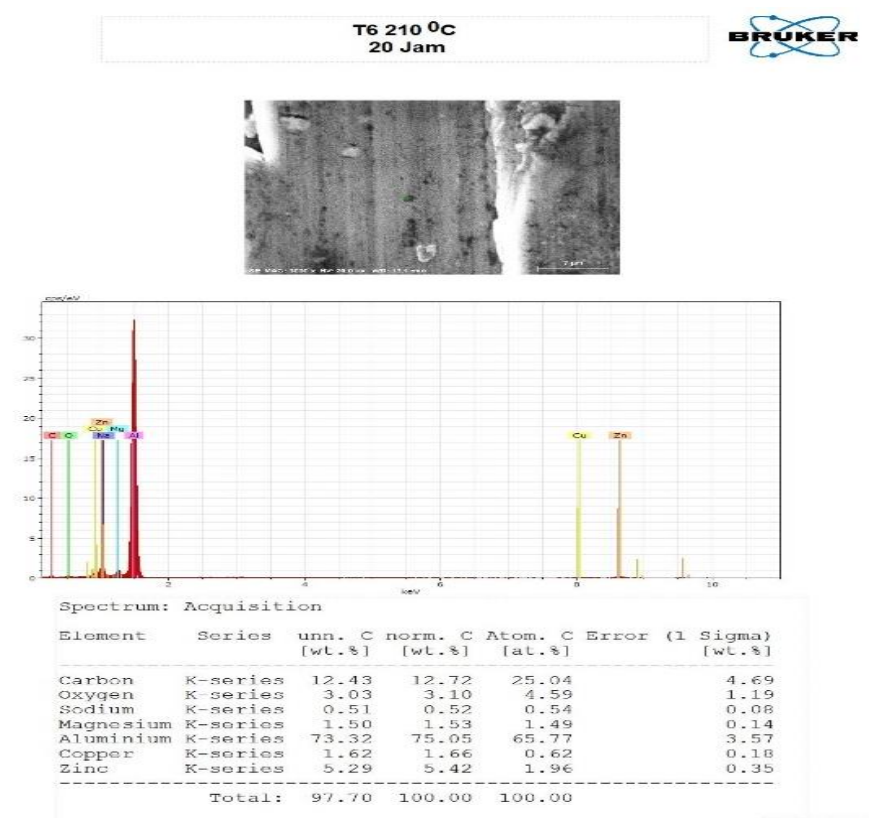

Sumber: Hasil Penelitian (2020)

Gambar 13. Pengujian SEM pada bahan AI 7075 dengan perlakuan panas penuaan buatan (Artificial Aged) selama 20 jam.

Dari hasil analisis bahan Aluminium 7075 dengan menggunakan metode SEM, menunjukkan bahwa dari gambar 4.6-8 struktur mikro Al 7075 non heat treatment terlihat matriks Al yang dominan, sedangkan pada Gambar 4.9-11, struktur mikro Al 7075 temperatur aging $210^{\circ} \mathrm{C}$ waktu aging 20 jam terlihat adanya fasa CuA12, AlCuMg, MgZn 2 . Hal ini sama dengan hasil penelitian dari Elvis A. Sumaraw dimana struktur Al 7075 temperatur aging $150^{\circ} \mathrm{C}$ Waktu aging 5 jam terlihat adanya fasa $\mathrm{CuA}_{2}$, AICuMg, MgZn $\mathrm{n}_{2}$ yang berfungsi mengeraskan paduan.

\section{Kesimpulan}

Berdasarkan penelitian yang dilakukan oleh penulis dapat disimpulkan sebagai berikut: a). Al 7075 mencapai kekerasan maksimum pada temperatur aging $210^{\circ} \mathrm{C}$ dan waktu aging 20 jam, yaitu sebesar 144,90 HV. Sedangkan pengujian nilai kekerasan sampel uji Al 7075 tanpa perlakuan panas memberikan nilai kekerasan hanya sebesar $84,10 \mathrm{HV}$, teijadi kanaikan nilai kekerasan sebesar 41,96\%. b). Struktur Mikro yang terbentuk dari paduan Al 7075 dengan tanpa perlakuan panas terlihat matriks Al yang mendominasi, sedangakan setelah melalui perlakuan panas T6 diketahui bahwa muncul fasa $\mathrm{CuA1}$, AlCuMg, MgZn2 yang berfungsi mengeraskan paduan. c). Dengan adanya perlakuan panas (Solid Solution) diatas $500{ }^{\circ} \mathrm{C}$ menyebabkan penurunan densitas dislokasi yang diikuti dengan bertambahnya regangan kisi. Sedangkan perlakuan panas penuaan buatan pada suhu $210^{\circ} \mathrm{C}$ menyebabkan penurunan Ukuran Kristal dari perlakuan panas (Solid Solution) pada suhu $570^{\circ} \mathrm{C}$ yang diikuti dengan bertambahnya Ukuran Kristal seiring dengan lamanya waktu pemanasan penuaan buatan. 
Submitted: 7 Nopember 2019; Revised: 21 Nopember 2019; Accepted: 5 Desember 2019; Published: 25 Januari 2020

Sedangkan densitas dislokasi dan regangan kisi meningkat selama periode waktu pemanasan 1 jam dan 4 jam, lalu pada waktu 20 jam mengalami penurunan densitas dislokasi serta regangan kisi.

\section{Daftar Pustaka}

Sofyan, E, \& Paripurno, D.A. (1994). "Karakterisasi aerodinamik sayap/sirip roket RX 420 subsonik dan supersonic", Proceeding Teknologi Dirgantara, Diskusi Teknik, LAPAN, ISBN/ISSN :9798554-00-0, tahun 1994, hal.120-129.

Djamin, M \& Budiarto. (1999). "Pengaruh waktu penuaan terhadap sifat fisik pada sintesa bahan paduan ingat bentuk CuNiAl" Prosiding Pertemuan dan Presentasi IImiah, P3TMBATAN, Yogyakarta, 14-15 Juli 1999.

Suhendar, B, Suyatman, Sungkono, C. (2006). "Persiapan pembuatan dan karakterisasi paduan ingat bentuk Cu-Al-Ni," Jurnal Sains Materi Indonesia Indonesian Journal of Materials Science Vol. 7, No. 3, Juni 2006, hal: 98 - 102 ISSN: 1411-1098

Smallman, R. E. \& Bishop, R. J., (2000). Metalurgi Fisik Modern dan Rekayasa Material, Edisi Keenam. Jakarta: Erlangga.

Beiser, A \& Liong, T.H. (1992). Konsep Fisika Modern, Edisi Keempat. Jakarta: Erlangga.

Van V, \& Lawrence H. (1985). IImu dan Teknologi Bahan. Edisi ke 5 (Djapri, Sriati, Trans), Jakarta: Erlangga.

Dieter, G.E. (1988). "Metalurgi Mekanik”, Edisi ke 3, jilid 2, Jakarta: Erlangga.

Djatmiko, E, \& Budiarto. (2011). Analisis sifat mekanis dan strukturmikro pada produk paduan Al78Si22 hasil pengecoran cara squeezing casting, Prosiding Seminar Nasional Pengembangan Energi Nuklir IV-2011, PPEN, BATAN, Jakarta

Mahallawy, N.A., Taha, M.A. \& Lotfizamzam, M. (1994). Journal of Materials Processing Technology; On the microstructure and mechanical properties of squeeze cast Al-7075 alloy, Vol. 40.

ASM Handbook. (2000). "Introduction to Aluminum Alloys and Tempers", ASM International.

ASTM Standard. (2004). "Standard Practice for Heat Treatment of Aluminum-Alloy Castings from All Processes".

ASTM Standard. (2004). "Standard Test Methods for Notched Bar Impact Testing of Metallic Materials".

Abdulwahab M., Madugu I.A., \& Yaro S.A. (2012). "Effects of Temper Conditions and StepQuenching -Ageing on the Hardness Characteristics and Yield Strength of A356.0-type Al-Si-Mg Alloy". Springer Science-Business. 